Article

\title{
Insecticidal and Biting Deterrent Activities of Magnolia grandiflora Essential Oils and Selected Pure Compounds against Aedes aegypti
}

\author{
Abbas Ali ${ }^{1, *}$, Nurhayat Tabanca ${ }^{1,2}$ (D), Betul Demirci ${ }^{3}$, Vijayasankar Raman ${ }^{1}$ (1), \\ Jane M. Budel ${ }^{4}$ (D), K. Hüsnü Can Baser ${ }^{5}$ (D) and Ikhlas A. Khan ${ }^{1}$ \\ 1 National Center for Natural Products Research, The University of Mississippi, Oxford, MS 38677, USA; \\ nurhayat.tabanca@usda.gov (N.T.); vraman@olemiss.edu (V.R.); ikhan@olemiss.edu (I.A.K.) \\ 2 United States Department of Agriculture, Agricultural Research Service (USDA-ARS), Subtropical \\ Horticulture Research Station (SHRS), Miami, FL 33158, USA \\ 3 Department of Pharmacognosy, Faculty of Pharmacy, Anadolu University, 26470 Eskisehir, Turkey; \\ betuldemirci@gmail.com \\ 4 Departamento de Ciências Farmacêuticas, Universidade Estadual de Ponta Grossa (UEPG), Ponta Grossa, \\ PR 84030-900, Brazil; janemanfron@hotmail.com \\ 5 Department of Pharmacognosy, Faculty of Pharmacy, Near East University, 99138 Nicosia, Northern Cyprus; \\ khcbaser@gmail.com \\ *CCorrespondence: aali@olemiss.edu or dr_aliabbas@hotmail.com
}

Academic Editor: Maria Carla Marcotullio

Received: 26 February 2020; Accepted: 14 March 2020; Published: 17 March 2020

\begin{abstract}
In our natural products screening program for mosquitoes, we tested essential oils extracted from different plant parts of Magnolia grandiflora $\mathrm{L}$. for their insecticidal and biting deterrent activities against Aedes aegypti. Biting deterrence of seeds essential oil with biting deterrence index value of 0.89 was similar to $\mathrm{N}, \mathrm{N}$-diethyl-3-methylbenzamide (DEET). All the other oils were active above the solvent control but the activity was significantly lower than DEET. Based on GC-MS analysis, three pure compounds that were only present in the essential oil of seed were further investigated to identify the compounds responsible for biting deterrent activity. 1-Decanol with PNB value of 0.8 was similar to DEET $(\mathrm{PNB}=0.8)$, whereas 1-octanol with PNB value of 0.64 showed biting deterrence lower than 1-decanol and DEET. The activity of 1-heptanol with PNB value of 0.36 was similar to the negative control. Since 1-decanol, which was $3.3 \%$ of the seed essential oil, showed biting deterrence similar to DEET as a pure compound, this compound might be responsible for the activity of this oil. In in vitro A \& K bioassay, 1-decanol with MED value of 6.25 showed higher repellency than DEET $(\mathrm{MED}=12.5)$. Essential oils of immature and mature fruit showed high toxicity whereas leaf, flower, and seeds essential oils gave only $20 \%, 0 \%$, and $50 \%$ mortality, respectively, at the highest dose of 125 ppm. 1-Decanol with $\mathrm{LC}_{50}$ of $4.8 \mathrm{ppm}$ was the most toxic compound.
\end{abstract}

Keywords: Magnoliaceae; GC-FID; GC-MS; mosquito control; 1-decanol; 1-octanol; larvicidal activity; deterrent; biopesticides

\section{Introduction}

Insect disease vectors transmit many disease pathogens and are important in global public health. Aedes aegypti (L.) and Ae. albopictus (Skuse) are the primary and secondary vectors of Zika and dengue as well as other viruses [1]. The use of synthetic insecticides in mosquito control has proven to be one of the major approaches for the prevention and reduction of mosquito-borne disease incidence [2]. Insect repellents also play an important role in the reduction of disease incidence by preventing infected mosquitoes from biting humans [3]. Moreover; repellents have always been used against host-seeking 
vectors as they provide immediate; localized; personal protection. $N, N$-Diethyl-3-methylbenzamide (DEET) has been in use for more than 60 years and is the gold standard to which all repellents are measured in the marketplace [4]. The discovery of novel insecticides and repellents against disease vectors from non-toxic and biodegradable plant sources continues to be the focus of recent research efforts [5-8].

Magnolia grandiflora L. (Magnoliaceae) is a large evergreen tree native to North America [9] that has medicinal and ornamental values. Medicinal use of various parts of M. grandiflora is reported in American Indian medicine and also listed as a bitter tonic and antimalarial. Several biologically active compounds have been reported from Magnolia species [10-12]. As a part of our natural product screening program for mosquitoes, we tested essential oils from various parts of M. grandiflora for their larvicidal and biting deterrent activities. This paper reports insecticidal and biting deterrent activities of essential oils and select pure compounds from various parts of $M$. grandiflora against yellow fever mosquito, Aedes aegypti.

\section{Results}

Water-distilled essential oils of the leaves, flowers, immature fruits, mature fruits, and seeds of M. grandiflora were analyzed by GC-FID and GC-MS. Chemical compositions of the essential oils and total ion current (TIC) chromatogram are given in Table 1 and Figure S1 (Suplementary Material). Chemical profiles of the oils varied among essential oils. Sesquiterpene hydrocarbons (31.5\%) were dominant in the seeds and immature fruit essential oils (32\%) whereas the leaf and flower oils were rich in monoterpene hydrocarbons (30.9\% and 43.8\%, respectively). Oxygenated monoterpenes (36.9\%) were the major components of the mature fruit oil followed by monoterpene hydrocarbons (15.2\%), sesquiterpene hydrocarbons (15.5\%), and oxygenated sesquiterpenes (16.2\%). The $\alpha$ - and $\beta$-pinenes and 1,8-cineole were the major contents of leaf, flower, immature fruit, and mature fruit whereas these compounds were either very low or absent in seed essential oil (Table 1). The seed oil was differentiated from other essential oils because of the presence of fatty acid; hexadecanoic acid ( $2.9 \%)$ and fatty acid esters $(2.2 \%)$. The saturated aliphatic esters $(10.9 \%)$ and two phenolic compounds; methyl chavicol $(2.6 \%)$ and eugenol (1.3\%) were also only found in the seed essential oil. Major compounds, $\alpha-$ and $\beta$-pinenes and 1,8-cineole present in leaf, flower, immature fruit, and fruit essential oils were either in very low concentration or absent in seed essential oil (Table 1). Fatty acids and esters (5.1\%) were high and aliphatic esters (10.9\%) were present only in the seed essential oil. Hexadecanoic acid (2.9\%), 1-decanol (3.3\%), 1-octanol (6.2\%), and 1-heptanol were also present only in the seed essential oil.

Table 1. The chemical composition of essential oils of the Magnolia grandiflora.

\begin{tabular}{|c|c|c|c|c|c|c|c|}
\hline RRI & Compound & Leaf $(\%)$ & $\begin{array}{c}\text { Flower } \\
(\%)\end{array}$ & $\begin{array}{l}\text { Immature } \\
\text { Fruit (\%) }\end{array}$ & $\begin{array}{c}\text { Mature } \\
\text { Fruit (\%) }\end{array}$ & Seed $(\%)$ & IM \\
\hline 1032 & $\alpha$-Pinene & 6.3 & 8.0 & 4.8 & 3.8 & 1.0 & RRI, MS \\
\hline 1076 & Camphene & 0.1 & 0.7 & 1.1 & 1.6 & - & RRI, MS \\
\hline 1100 & Isobutyl isobutyrate & - & - & - & - & 0.7 & MS \\
\hline 1132 & Sabinene & - & 0.3 & - & - & - & RRI, MS \\
\hline 1151 & Propyl 2-methylbutyrate & - & - & - & - & 1.0 & MS \\
\hline 1174 & Myrcene & - & 0.4 & - & - & 0.6 & RRI, MS \\
\hline 1176 & $\alpha$-Phellandrene & - & - & - & - & 1.1 & RRI, MS \\
\hline 1213 & 1,8-Cineole & 4.1 & 4.4 & 4.5 & 12.2 & - & RRI, MS \\
\hline 1218 & $\beta$-Phellandrene & - & - & - & - & 7.3 & RRI, MS \\
\hline 1241 & Butyl-2-methylbutyrate & - & - & - & - & 1.3 & MS \\
\hline
\end{tabular}


Table 1. Cont

\begin{tabular}{|c|c|c|c|c|c|c|c|}
\hline RRI & Compound & Leaf $(\%)$ & $\begin{array}{c}\text { Flower } \\
(\%)\end{array}$ & $\begin{array}{c}\text { Immature } \\
\text { Fruit (\%) }\end{array}$ & $\begin{array}{c}\text { Mature } \\
\text { Fruit (\%) }\end{array}$ & Seed $(\%)$ & IM \\
\hline 1246 & $(Z)$ - $\beta$-Ocimene & - & 0.8 & - & - & - & MS \\
\hline 1280 & $p$-Cymene & 0.4 & 0.3 & 0.8 & 1.3 & 5.5 & RRI, MS \\
\hline 1290 & Terpinolene & - & - & 0.5 & 0.2 & - & RRI, MS \\
\hline 1286 & 2-Methyl butyl 2-methylbutyrate & - & - & - & - & 1.3 & MS \\
\hline 1299 & 2-Methylbutyl isovalerate & - & - & - & - & 0.8 & MS \\
\hline 1429 & Perillene & - & - & - & - & 0.4 & MS \\
\hline 1450 & trans-Linalool oxide (Furanoid) & - & 0.8 & - & - & - & MS \\
\hline 1452 & $\alpha, p$-Dimethylstyrene & 0.2 & - & - & 0.3 & - & MS \\
\hline 1463 & 1-Heptanol & - & - & - & - & 0.5 & MS \\
\hline 1493 & $\alpha$-Ylangene & - & - & - & - & 0.7 & MS \\
\hline 1497 & $\alpha$-Copaene & - & - & 0.2 & 0.2 & 1.6 & RRI, MS \\
\hline 1532 & Camphor & - & - & - & 0.3 & - & RRI, MS \\
\hline 1553 & Linalool & 0.7 & 4.7 & 0.5 & 0.8 & - & RRI, MS \\
\hline 1562 & 1-Octanol & - & - & - & - & 6.2 & MS \\
\hline 1586 & Pinocarvone & 0.3 & - & 0.3 & 1.8 & - & RRI, MS \\
\hline 1591 & Bornyl acetate & - & 0.2 & 2.8 & 4.1 & 0.4 & RRI, MS \\
\hline 1594 & trans- $\beta$-Bergamotene & 0.3 & 1.2 & 0.7 & 0.4 & 1.7 & MS \\
\hline 1600 & $\beta$-Elemene & 13.6 & 7.7 & 12.9 & 5.7 & - & MS \\
\hline 1611 & Terpinen-4-ol & 0.8 & 0.6 & 1.1 & 0.8 & - & RRI, MS \\
\hline 1612 & $\beta$-Caryophyllene & 3.4 & 1.1 & 7.9 & 2.9 & 8.8 & RRI, MS \\
\hline 1648 & Myrtenal & 1.1 & 0.9 & 0.7 & 4.0 & - & MS \\
\hline 1661 & trans-Pinocarvyl acetate & 3.8 & 3.3 & 1.5 & 2.3 & - & MS \\
\hline 1669 & Sesquisabinene & - & - & - & - & 1.7 & MS \\
\hline 1670 & trans-Pinocarveol & 0.9 & 0.8 & 0.5 & 2.4 & - & RRI, MS \\
\hline 1687 & $\alpha$-Humulene & 0.8 & 0.4 & 1.4 & 0.6 & 1.0 & RRI, MS \\
\hline 1687 & Methyl chavicol & - & - & - & - & 2.6 & RRI, MS \\
\hline 1688 & Selina-4,11-diene & 0.4 & 0.3 & 1.1 & - & - & MS \\
\hline 1695 & $(E)$ - $\beta$-Farnesene & - & - & - & - & 0.4 & MS \\
\hline 1704 & Myrtenyl acetate & - & - & - & - & - & MS \\
\hline 1704 & $\gamma$-Muurolene & - & - & 0.6 & 0.5 & 2.7 & MS \\
\hline 1706 & $\alpha$-Terpineol & 2.4 & 2.5 & 5.1 & 3.9 & - & RRI, MS \\
\hline 1719 & Borneol & 0.2 & - & 0.7 & 1.2 & - & RRI, MS \\
\hline 1725 & Verbenone & - & - & - & 0.7 & - & RRI, MS \\
\hline 1726 & Germacrene D & - & 0.3 & - & - & - & RRI, MS \\
\hline 1740 & $\alpha$-Muurolene & - & - & - & - & 1.6 & MS \\
\hline 1742 & Geranial & - & 0.5 & - & - & - & RRI, MS \\
\hline 1742 & $\beta$-Selinene & 1.5 & 1.2 & 2.9 & 1.6 & 0.9 & MS \\
\hline 1744 & $\alpha$-Selinene & 1.4 & 0.9 & 2.3 & 1.5 & 0.7 & MS \\
\hline 1766 & 1-Decanol & - & - & - & - & 3.3 & MS \\
\hline 1773 & $\delta$-Cadinene & - & 0.3 & 1.3 & 0.3 & 4.0 & MS \\
\hline 1776 & $\gamma$-Cadinene & - & 0.1 & - & 0.5 & 2.0 & MS \\
\hline 1784 & $(E)$ - $\alpha$-Bisabolene & 0.4 & 0.6 & 1.2 & 0.4 & 0.8 & MS \\
\hline 1799 & Cadina-1,4-diene & - & - & - & - & 0.3 & MS \\
\hline 1804 & Myrtenol & 1.5 & 1.4 & 0.5 & 2.2 & - & MS \\
\hline 1808 & Nerol & - & 0.1 & - & - & - & RRI, MS \\
\hline 1849 & Calamenene & - & - & 0.5 & 0.4 & 1.8 & MS \\
\hline 1857 & Geraniol & - & 2.5 & - & - & - & RRI, MS \\
\hline 1864 & $p$-Cymen-8-ol & 1.0 & 0.4 & - & 0.6 & - & RRI, MS \\
\hline 1872 & cis-Myrtanol & - & $\operatorname{tr}$ & - & - & - & MS \\
\hline 1879 & trans-Myrtanol & - & 0.2 & - & - & - & MS \\
\hline
\end{tabular}


Table 1. Cont.

\begin{tabular}{|c|c|c|c|c|c|c|c|}
\hline RRI & Compound & Leaf $(\%)$ & $\begin{array}{l}\text { Flower } \\
(\%)\end{array}$ & $\begin{array}{l}\text { Immature } \\
\text { Fruit }(\%)\end{array}$ & $\begin{array}{c}\text { Mature } \\
\text { Fruit }(\%)\end{array}$ & Seed $(\%)$ & IM \\
\hline 1941 & $\alpha$-Calacorene & - & - & 0.2 & 0.2 & 0.9 & MS \\
\hline 2008 & Caryophyllene oxide & 3.9 & 0.9 & 1.8 & 7.2 & 1.9 & RRI, MS \\
\hline 2029 & Perilla alcohol & - & - & - & 0.3 & - & MS \\
\hline 2071 & Humulene epoxide-II & 0.6 & 0.2 & 0.3 & 1.2 & - & MS \\
\hline 2080 & Junenol (=Eudesm-4(15)-en-6-ol) & - & 0.2 & - & - & - & MS \\
\hline 2100 & Heneicosane & - & 0.5 & - & - & - & RRI, MS \\
\hline 2186 & Eugenol & - & - & - & - & 1.3 & RRI, MS \\
\hline 2187 & T-Cadinol & 0.3 & 0.5 & 0.7 & 0.2 & 0.3 & MS \\
\hline 2219 & $\delta$-Cadinol & - & - & 0.2 & - & - & MS \\
\hline 2255 & $\alpha$-Cadinol & 0.3 & 1.3 & 1.4 & 0.7 & 0.3 & MS \\
\hline 2256 & Cadalene & - & - & - & - & 0.7 & MS \\
\hline 2262 & Ethyl hexadecanoate & - & - & - & - & 0.7 & MS \\
\hline 2269 & Guaia-6,10(14)-dien-4 $\beta$-ol & 0.3 & - & 0.6 & 0.7 & - & MS \\
\hline 2273 & Selin-11-en- $4 \alpha$-ol & 1.0 & 1.8 & 4.0 & 1.5 & - & MS \\
\hline 2300 & Tricosane & - & 0.6 & - & - & - & RRI, MS \\
\hline 2316 & $\begin{array}{l}\text { Caryophylla-2(12),6(13)-dien-5 } \beta \text {-ol } \\
\text { (=Caryophylladienol I) }\end{array}$ & - & - & - & 1.4 & - & MS \\
\hline 2509 & $\begin{array}{c}\text { (Z.Z)-9,12-methyl octadecadienoate } \\
\text { (=Methyl linoleate) }\end{array}$ & - & - & - & - & 0.7 & RRI, MS \\
\hline \multirow[t]{9}{*}{2931} & Hexadecanoic acid & - & - & 0.5 & - & 2.9 & RRI, MS \\
\hline & Monoterpene hydrocarbons & 30.9 & 43.8 & 21.6 & 15.2 & 17.7 & \\
\hline & Oxygenated monoterpenes & 16.8 & 23.3 & 18.2 & 36.9 & 0.4 & \\
\hline & Sesquiterpene hydrocarbons & 21.4 & 13.5 & 32.0 & 15.5 & 31.5 & \\
\hline & Oxygenated Sesquiterpenes & 8.4 & 10.3 & 11.7 & 16.2 & 4.6 & \\
\hline & Fatty acids and their esters & 0.4 & - & 2.8 & - & 5.1 & \\
\hline & Aliphatic esters & - & - & - & - & 10.9 & \\
\hline & others & 0.2 & 2.1 & - & 0.3 & 15.0 & \\
\hline & Total & 78.1 & 93.0 & 86.3 & 84.1 & 85.2 & \\
\hline
\end{tabular}

RRI: relative retention indices calculated against $n$-alkanes; \%: calculated from FID data; tr: trace $(<0.1 \%)$; IM: identification method based on the relative retention indices (RRI) of authentic compounds on the HP Innowax column; MS, identified based on computer matching of the mass spectra with those of the Wiley and MassFinder libraries and comparison with literature data. \% calculated from FID data.; -: not detected.

The essential oils obtained from five different plant parts of $M$. grandiflora were investigated for their biting deterrent activity against Ae. aegypti. All the essential oils showed biting deterrence above the negative control. Seeds essential oil produced significantly higher biting deterrence than the essential oils from the other parts (Figure 1). Seed essential oil with high minimum effective dose BDI value (0.89) showed biting deterrent activity similar to DEET whereas all the other essential oils had activity lower than DEET. 1-Decanol with PNB value of 0.8 showed biting deterrence similar to DEET $(\mathrm{PNB}=0.8)$ whereas the activity of 1-octanol was above negative control but lower than DEET and 1-decanol (Figure 2). 


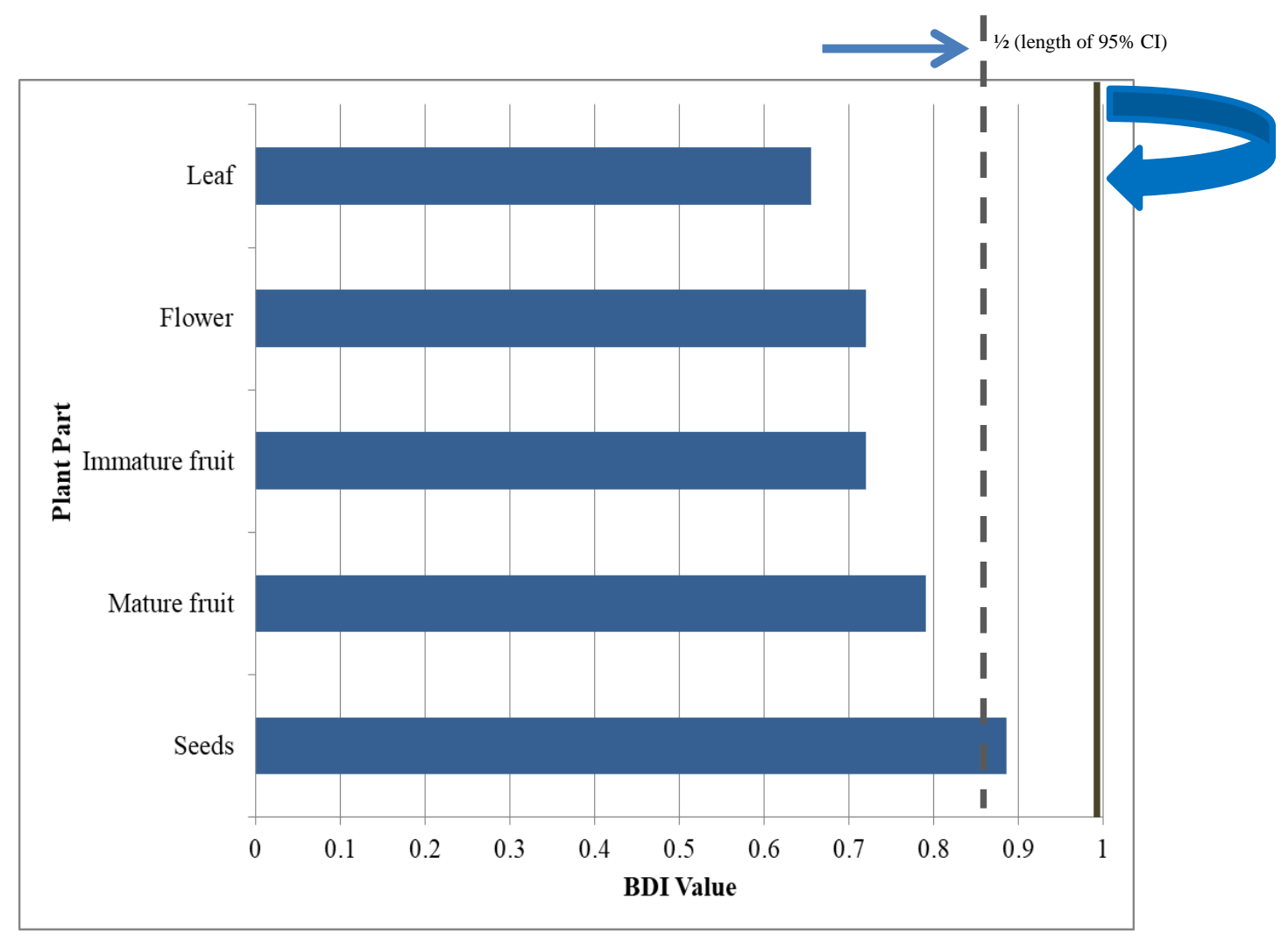

Figure 1. Mean BDI ( \pm SEM) values of the essential oils from different parts of $M$. grandiflora against Ae. aegypti. All the essential oils were tested at $10 \mu \mathrm{g} / \mathrm{cm}^{2}$ whereas DEET ( $N, N$-diethyl-3-methylbenzamide) was tested at $25 \mathrm{nmol} / \mathrm{cm}^{2}$ and ethanol a solvent control. A BDI value greater than 0 indicates biting deterrence relative to ethanol and a BDI value not significantly different from 1 shows deterrence similar to DEET.

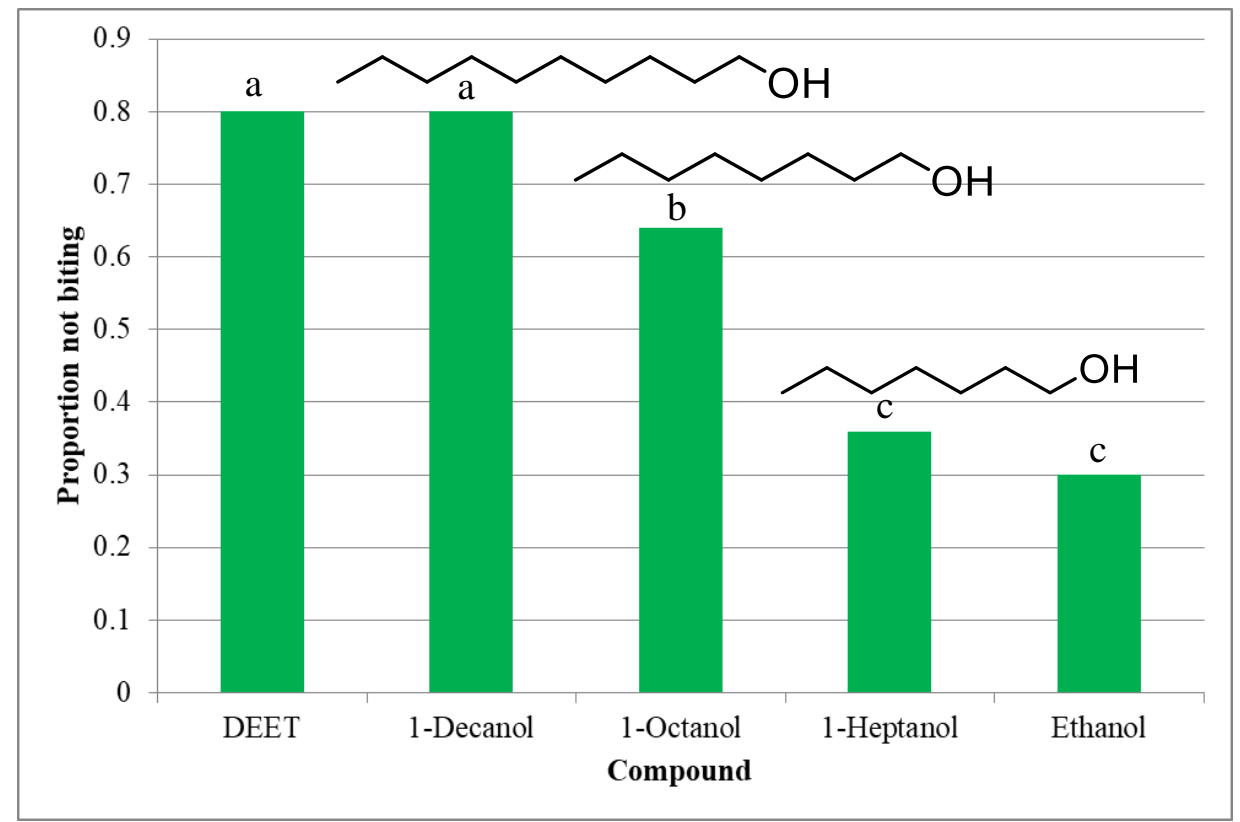

Figure 2. Mean proportion not biting values of the essential oils from different parts of M. grandiflora against Ae. aegypti. Essential oils were tested at $10 \mu \mathrm{g} / \mathrm{cm}^{2}$ while DEET at $25 \mathrm{nmol} / \mathrm{cm}^{2}$ was tested as a positive control. Mean proportions sharing the same letter are not significantly different. 
Biting deterrence of 1-heptanol was similar to the negative control. 1-Decanol with 3.3\% of seed essential oil appears to be the major compound responsible for the biting deterrent activity of the seed essential oil. In in vitro A \& K bioassay, MED value of 1-decanol (6.25) was lower than DEET (12.5) which indicated better repellency of 1-decanol than DEET (Figure 3).

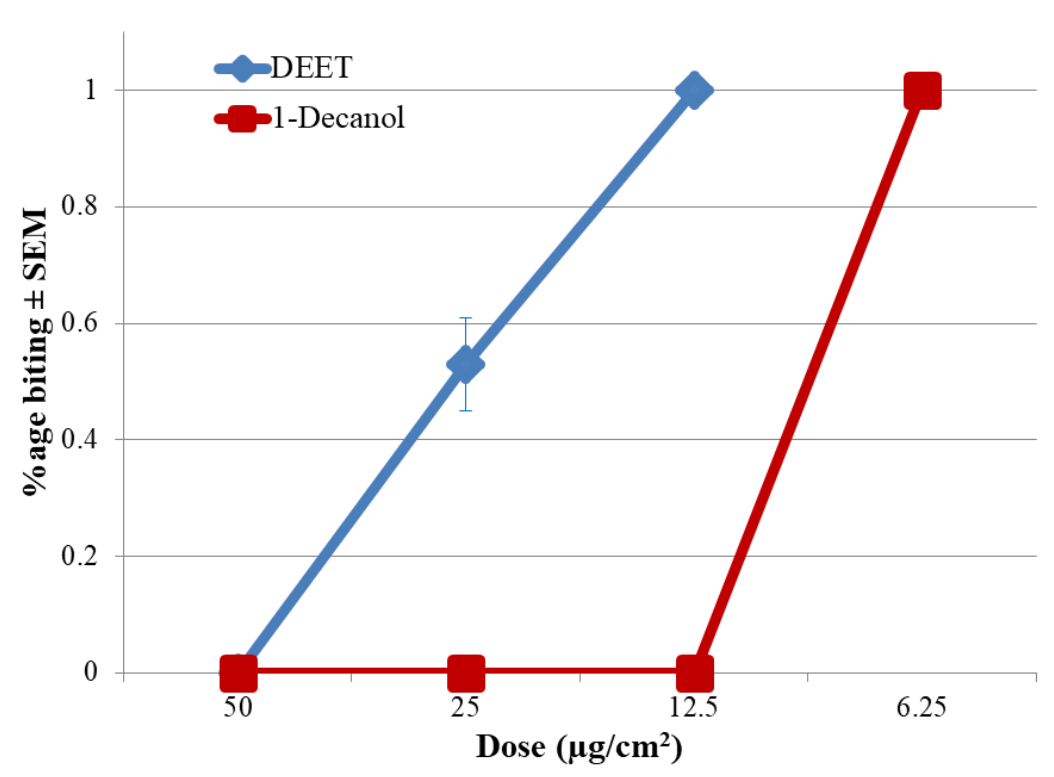

Figure 3. Data are \%age (mean $\pm \mathrm{SEM}$ ) females biting. Minimum effective dosage (MED) values in this bioassay were $\leq 1 \%$ biting in 1 min which is two females out of 200 in this cage.

The toxicity of essential oils from $M$. grandiflora against 1-d-old larvae of Ae. aegypti is given in Table 2. In initial screening, essential oils of immature and mature fruits showed high toxicity whereas leaf, flower, and seeds essential oils gave only 20\%, 0\%, and 50\% mortality, respectively, at the highest screening dose of 125 ppm. Therefore dose-response bioassays were not conducted on leaf, flower, and seeds essential oils. Immature fruit and mature fruit essential oils with $\mathrm{LC}_{50}$ values of 49.4 and 48.9 ppm, respectively at 24-h post-treatment showed similar toxicity.

Table 2. Toxicity of essential oils from M. grandiflora and its select pure compounds against 1-day-old Ae. aegypti at 24-h post-treatment.

\begin{tabular}{ccccc}
\hline Essential oil & LC $_{\mathbf{5 0}} \mathbf{( 9 5 \% C I ) ~}^{*}$ & LC $_{\mathbf{9 0}} \mathbf{( 9 5 \% \mathbf { C I } )}$ & $\boldsymbol{\chi}^{\mathbf{2}}$ & DF \\
\hline Immature fruit & $49.4(39.4-64.2)$ & $135.9(96.5-244.2)$ & 43.0 & 48 \\
Mature fruit & $48.9(42.3-56.9)$ & $116.9(94.6-158.3)$ & 83.3 & 48 \\
1-Decanol & $4.8(4.2-5.5)$ & $10.2(8.5-13.2)$ & 83.2 & 48 \\
1-Octanol & $34.3(30.3-38.7)$ & $63.9(54.4-80.5)$ & 73.7 & 48 \\
Leaf & $20 \% * *$ & & & \\
Flower & $0 \%$ & & & \\
Seed & $50 \%$ & &
\end{tabular}

\footnotetext{
* $\mathrm{LC}_{50}$ and $\mathrm{LC}_{90}$ values are in ppm and $95 \%$ C.I are confidence intervals. ${ }^{* *}$ Leaf, flower and seeds essential oils gave only $20 \%, 0$ and $50 \%$ mortality, respectively, at the highest dose of $125 \mathrm{ppm}$.
}

Pure compounds 1-decanol, 1-octanol, and 1-heptanol, present in seed essential oil were also screened for larvicidal activity. Both 1-decanol and 1-octanol were active in screening bioassays whereas 1-heptanol did not show any mortality at the highest dose of $125 \mathrm{ppm}$. 1-Decanol and 1-octanol were further evaluated to observe the dose response. 1-Decanol with $\mathrm{LC}_{50}$ of $4.8 \mathrm{ppm}$ was the most toxic compound followed by 1-octanol $\left(\mathrm{LC}_{50}=34.3 \mathrm{ppm}\right)$ at 24-h post-treatment. 1-Decanol was very toxic $\left(\mathrm{LC}_{50}=4.8 \mathrm{ppm}\right)$ as a pure compound, the seed essential oil that contained $3.3 \%$ of this compound showed $50 \%$ mortality at the highest dose of $125 \mathrm{ppm}$. 1-Decanol amounted to be $4.07 \mathrm{ppm}$ as a part of 
seed essential oil at $125 \mathrm{ppm}$ which caused mortality similar to the pure compound. 1-Decanol and 1-octanol amounted to be 4.07 and 7.75 ppm, respectively, as a part of the essential oil dose of $125 \mathrm{ppm}$. Since the toxicity of 1-octanol as a pure compound was low, the main compound responsible for the toxicity of the seed essential oil appears to be 1-decanol.

\section{Discussion}

Schuhly et al. [13] reported $\beta$-elemene as the major compound in the fruit essential oil of $M$. grandiflora which corroborates the finding of this study having $\beta$-elemene $(6-14 \%)$ in all the essential oils of M. grandiflora except seed oil. Guerra-Boone et al. [14] reported bornyl acetate (20.9\%) as the major compound in M. grandiflora leaf oil, however, we did not detect this compound in the leaf oil. Garg and Kumar [15] reported $\beta$-caryophyllene as the major compound (34.8\%) in flower essential oil whereas only a small amount (1.1\%) was detected in the present study. Farag and Al-Mahdy [16] reported variation in the contents of $M$. grandiflora flower oil volatiles obtained through headspace and water distillation techniques indicating the effects of the isolation technique on the yield of different compounds. Such differences in chemical compositions of essential oils are expected and can be attributed to many factors including geographic location, genetic factors, climate, crop stage, harvesting time, and processing method $[17,18]$.

In our previous studies, some of the compounds that were present in these essential oils exhibited very insignificant biting deterrence. $\alpha$-Phellandrene $(\mathrm{BDI}=0.52),(+)$ - $\alpha$-pinene $(\mathrm{BDI}=0.47)$, $(-)$ - $\alpha$-pinene $(B D I=0.41),(+)-\beta$-pinene $(B D I=0.57),(-)-\beta$-pinene $(B D I=0.51), p$-cymene $(B D I=0.48)$, trans-sabinene hydrate $(\mathrm{BDI}=0.61)$ showed biting deterrent activity lower than DEET. $\beta$-caryophyllene and caryophyllene oxide with BDI values of 0.54 and 0.66 , respectively, were also significantly lower than DEET at $25 \mathrm{nmol} / \mathrm{cm}^{2}$ and these two sesquiterpenes also did not repel mosquitoes up to the highest dose of $1.5 \mathrm{mg} / \mathrm{cm}^{2}$ in cloth patch assay [6,19-22]. Hexadecanoic acid that was only present in seed essential oil was reported to have biting deterrence lower $(\mathrm{PNB}=0.72)$ than DEET [23]. In our previous study, we found that mid-chain length acids $\left(C_{10: 0}\right.$ to $\left.C_{13: 0}\right)$ showed the highest biting deterrent activity against Ae. aegypti as compared to short-chain length acids $\left(\mathrm{C}_{6: 0}\right.$ to $\left.\mathrm{C}_{9: 0}\right)$ [22]. The current study reveals similar pattern of medium chain length fatty alcohol $\left(C_{10: 0}\right)$ had higher biting deterrent activity than short-chain length alcohol $\left(\mathrm{C}_{8: 0}\right)$. However, we shall work on this hypothesis and confirm the activity toward short, med, and long-chain fatty alcohols. Many methylbutyrates present in the seed essential oil were tested in our screening program and found not active as biting deterrents (Ali personal communications). Since most of the major compounds that were present only in seed essential oil did not show any significant activity, 1-decanol might be the main compound responsible for the biting deterrent activity of M. grandiflora seed essential oil.

The toxicity of many natural compounds present in plant essential oils against mosquitoes has been reported in the literature. $\alpha$-Pinene $\left(\mathrm{LC}_{50}=49.5 \mathrm{ppm}\right), \beta$-pinene $\left(\mathrm{LC}_{50}=35.9 \mathrm{ppm}\right), \beta$-caryophyllene $\left(\mathrm{LC}_{50}=26.0 \mathrm{ppm}\right)$, and caryophyllene oxide $\left(\mathrm{LC}_{50}=29.8 \mathrm{ppm}\right)$ were active as larvicides against $A e$. aegypti whereas 1,8-cineole did not show any mortality at the highest screening dose of 125 ppm [19,23]. Monoterpenes that were present in variable concentrations in these essential oils showed larvicidal activity. These higher percentages of monoterpenes ( $\alpha$ - and $\beta$-pinenes) in combination with other compounds may be responsible for the high toxicity of immature- and mature fruit essential oils. We will further explore other compounds present in $M$. grandiflora essential oils for their potential as larvicides against mosquitoes. Ethanolic extracts of sarcotesta of the seeds of $M$. dealbata were reported to have $96.4 \%$ mortality at $0.1 \mathrm{mg} / \mathrm{mL}$ against the Mexican fruit fly (Anastrepha ludens Loew) whereas the extracts from the other parts were inactive [24]. 


\section{Materials and Methods}

\subsection{Chemicals}

Individual compounds such as 1-decanol (CAS \# 112-30-1), 1-octanol (CAS\# 111-87-5), and 1-heptanol (CAS \# 111-70-6) were obtained from the National Center for Natural Products Research (NCNPR) Repository of The University of Mississippi, University, MS, USA Repository. These compounds were previously purchased from Sigma-Aldrich Co., St. Louis, MO, USA.

\subsection{Plant Materials}

Whole samples of leaves, flowers, immature and mature fruits, and seeds (Figure 4) were freshly collected from an identified M. grandiflora tree at the University of Mississippi campus in 2018. Voucher specimens of all the samples-leaves (NCNPR \# 20286), stem-bark (\# 20874), flowers (\# 20316), immature fruit (\# 20871), mature fruit with seeds removed (\# 20872), and seeds (\# 20873)—were deposited in the Repository of Botanicals at NCNPR, University of Mississippi.
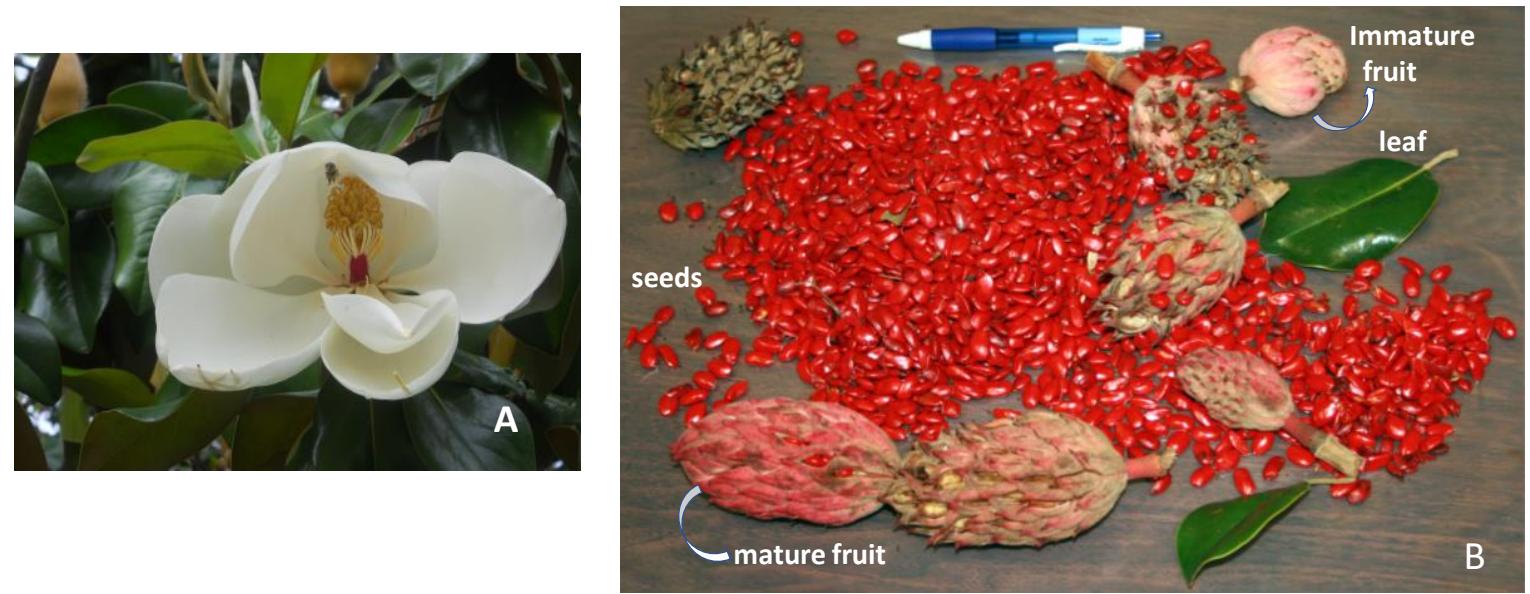

Figure 4. Study material. A: flowers; B: leaves, immature fruits, mature fruits and seeds. Photos courtesy of V.R.

\subsection{Extraction of Essential Oils}

For the extraction of essential oils, leaves, flowers, immature and mature fruits, and seeds of $M$. grandiflora were separately subjected to hydrodistillation for $3 \mathrm{~h}$, using a modified Clevenger-type apparatus. Seeds were crushed in a mortar and pestle before hydrodistillation (Figure 5). The resultant oils were stored in glass vials at $4 \pm 0.5^{\circ} \mathrm{C}$ with no light. The yields were calculated on a moisture-free basis for mature fruits, flowers, seeds, immature fruits and leaves at $0.02,0.06,0.1,0.1,1.5 \%$ respectively whereas there was no oil present in the stem-bark sample.
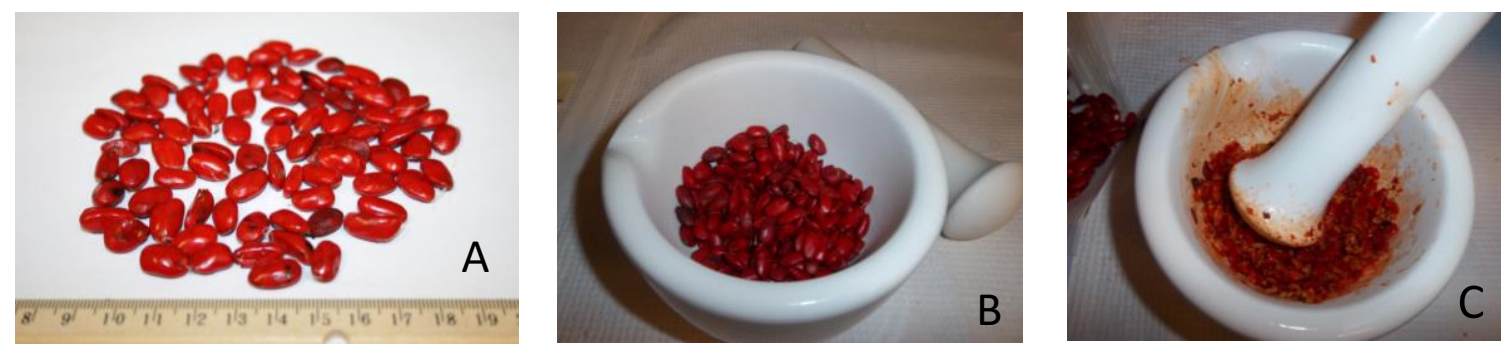

Figure 5. Study material. A: Seeds were separated from mature fruits; B: seeds were prepared and gently crushed in a mortar and pestle (C), and were subsequently hydrodistilled. Photos courtesy of V.R and N.T. 


\subsection{GC-MS Analysis}

The GC-MS analysis was carried out with an Agilent 5975 GC-MSD system Agilent 5975 (SEM Ltd., Istanbul, Turkey). Innowax FSC column $(60 \mathrm{~m} \times 0.25 \mathrm{~mm}, 0.25 \mu \mathrm{m}$ film thickness) was used with helium as the carrier gas $(0.8 \mathrm{~mL} / \mathrm{min})$. GC oven temperature was kept at $60^{\circ} \mathrm{C}$ for $10 \mathrm{~min}$ and programmed to $220^{\circ} \mathrm{C}$ at a rate of $4{ }^{\circ} \mathrm{C} / \mathrm{min}$, and kept constant at $220^{\circ} \mathrm{C}$ for $10 \mathrm{~min}$ and then programmed to $240{ }^{\circ} \mathrm{C}$ at a rate of $1^{\circ} \mathrm{C} / \mathrm{min}$. The split ratio was adjusted at 40:1. The injector temperature was set at $250{ }^{\circ} \mathrm{C}$. Mass spectra were recorded at $70 \mathrm{eV}$. The mass ranged from $\mathrm{m} / \mathrm{z} 35$ to 450 .

\subsection{GC Analysis}

The GC analysis was carried out using an Agilent 6890N GC system Agilent 5975 (SEM Ltd., Istanbul, Turkey). The FID detector temperature was $300{ }^{\circ} \mathrm{C}$. To obtain the same elution order with GC-MS, simultaneous auto-injection was done on a duplicate of the same column applying the same operational conditions. Relative percentage amounts of the separated compounds were calculated from FID chromatograms. The analysis results are given in Table 1.

Identification of the essential oil components was carried out by comparison of their relative retention times with those of authentic samples or by comparison of their relative retention index (RRI) to series of $n$-alkanes $[25,26]$. Computer matching against commercial (Wiley GC/MS Library, MassFinder Software 4.0) and in-house "Başer Library of Essential Oil Constituents" which includes over 3200 genuine compounds with MS and retention data from pure standard compounds and components of known oils as.

\subsection{Insects}

Aedes aegypti used in these studies were from a laboratory colony maintained at the Mosquito and Fly Research Unit, Center for Medical, Agricultural and Veterinary Entomology, USDA-ARS, Gainesville, Florida since 1952. We received the eggs and stored them in our laboratory until needed. Mosquitoes were reared to the adult stage by feeding the larvae on a larval diet of $2 \%$ slurry of $3: 2$ beef liver powder (now Foods, Bloomingdale, Illinois) and Brewer's yeast (Lewis Laboratories Ltd., Westport, CT, USA). The eggs were hatched and reared to the pupal stage in an environment-controlled room at a temperature of $27^{\circ} \mathrm{C} \pm 2{ }^{\circ} \mathrm{C}$ and $60 \pm 10 \% \mathrm{RH}$ in a photoperiod regimen of $12: 12$ (L: D) h. The adults were fed on cotton pads moistened with a $10 \%$ sucrose solution placed on the top of screens of 4-L cages.

\subsection{Mosquito Biting Bioassay}

Bioassays were conducted using a six-celled in vitro Klun and Debboun (K \& D) module bioassay system developed by Klun et al. [27] for quantitative evaluation of biting deterrent properties of compounds. The K \& D system consists of a six-well reservoir with each of the $4 \times 3 \mathrm{~cm}$ wells containing $6 \mathrm{~mL}$ of feeding solution. We used the CPDA-1 \pm ATP solution instead of human blood [22]. CPDA-1 and ATP preparations were freshly made on the day of the test and contained a green fluorescent tracer dye (fluorescent water-based tracer "Green"; www.blacklightworld.com) that allowed for the identification of mosquitoes that were fed on the solution. The squashed mosquitoes were observed under black light (FEIT, BPESL15T/BLB 13W 120VAC 60Hz 200mA, Ul\#E170906) for feeding. DEET (97\% purity N,N-diethyl-3-methylbenzamide) was used as a positive control (Sigma-Aldrich Co., St. Louis, MO, USA) and ethanol (Fisher Scientific Chemical Co. Fairlawn, NJ, USA) was used as solvent control. Stock and dilutions of all extracts and DEET were prepared in ethanol. All essential oils were evaluated at dosages of $10 \mu \mathrm{g} / \mathrm{cm}^{2}$ and DEET along with the pure compounds was tested at a concentration of $25 \mathrm{nmol} / \mathrm{cm}^{2}$.

The temperature of the solution was maintained at $37^{\circ} \mathrm{C}$ by using a circulatory bath. The test compounds and controls were randomly applied to six $4 \times 3 \mathrm{~cm}$ marked portions of nylon organdy strip, which was positioned over the six, membrane-covered wells. A six-celled K \& D module 
containing five 6-15-day-old females per cell was positioned over the six wells, trap doors were opened and mosquitoes allowed access for 3 minutes, after which they were collected back into the module. Mosquitoes were squashed and the presence of green dye (or not) in the gut was used as an indicator of feeding. A replicate consisted of six treatments: four samples, DEET, and ethanol as solvent control. Five replicates were conducted per day using new batches of mosquitoes in each replication.

\subsection{In vitro $A \mathcal{E}$ K Repellent Bioassay}

Bioassays were conducted using Ali and Khan (A \& K) bioassay system developed by Ali et al. [28] for quantitative evaluation of repellency against mosquitoes. Minimum effective dosage (MED) values in this bioassay were determined using a method described by Katritzky et al. [29]. Briefly, the bioassay system consists of a $30 \times 30 \times 30 \mathrm{~cm}$ collapsible aluminum cage having one penal of clear transparent acrylic sheet with $120 \times 35 \mathrm{~mm}$ slit through which the blood box containing a removable feeding device was attached. The top of the blood box had a sliding door used to expose the females to the treatment during the bioassay. Rectangular areas of $4 \times 7.5-\mathrm{cm}$ were marked on the collagen sheet that matched the measurement of the rectangular liquid reservoirs. Treatments were applied in a volume of $107 \mu \mathrm{L}$ using a micropipette. Treated collagen was secured on the feeding reservoir containing the feeding solution using a thin layer of grease (Dow Coming Corp., Midland, MI, USA). The feeding device was then pushed inside the blood box and the sliding door was opened to expose the females to the treatment. The numbers of females landing and biting were recorded visually for $1 \mathrm{~min}$. To ensure proper landing and biting, we used 3-4 cages at a time and only one treatment replication of individual compounds was completed in a single cage. The data are presented as \%age biting as a function of concentration. MED is $\leq 1 \%$ biting out of 200 females in the cage. A total of five replicates were conducted.

\subsection{Larval Bioassay}

Bioassays were conducted using the bioassay system described by Pridgeon et al. [30] to determine the larvicidal activity of essential oils from different parts of Magnolia grandiflora against Ae. aegypti. Eggs were hatched and larvae were held overnight in the hatching cup in a temperature-controlled room maintained at a temperature of $27 \pm 2{ }^{\circ} \mathrm{C}$ and $60 \pm 10 \% \mathrm{RH}$. Five 1-day-old larvae were transferred in each of 24 -well tissue culture plates in a $40-50 \mu \mathrm{L}$ droplet of water. Total of $50 \mu \mathrm{L}$ of larval diet $(2 \%$ slurry of 3:2 beef liver powder and brewer's yeast) and $1 \mathrm{~mL}$ of deionized water were added to each well by using a Finnpipette stepper (Thermo Fisher, Vantaa, Finland). All the essential oils and pure compounds were diluted in DMSO. After the treatment, the plates were swirled in clock-wise and counter-clockwise motions and front and back and side to side five times to ensure even mixing of the chemicals. Larval mortality was recorded 24 -h post-treatment. Larvae that showed no movement in the well after manual disturbance were recorded as dead. A series of 4-5 dosages were used in each treatment to get a range of mortality. Treatments were replicated ten times for each extract/compound.

\subsection{Statistical Analyses}

Proportion not biting (PNB) was calculated using the procedure described by Ali et al. [22]. As the K \& D module bioassay system can handle only four treatments along with negative and positive controls to make direct comparisons among more than four test compounds and to compensate for variation in overall response among replicates, biting deterrent activity was quantified as biting deterrence index (BDI) [22]. The BDI's were calculated using the following formula:

$$
\left[B D I_{i, j, k}\right]=\left[\begin{array}{ll}
P N B_{i, j, k}-P N B_{c, j, k} \\
\hline P N B_{d, j, k}-P N B_{c, j, k}
\end{array}\right]
$$

where $\mathrm{PNB}_{i, j, k}$ denotes the proportion of females not biting when exposed to test compound $i$ for replication $j$ and day $k(i=1-4, j=1-5, k=1-2), \mathrm{PNB}_{c, j, k}$ denotes the proportion of females not biting the solvent control " $c$ " for replication $j$ and day $k(j=1-5, k=1-2)$ and $\mathrm{PNB}_{d, j, k}$ denotes the proportion 
of females not biting in response to DEET " $d$ " (positive control) for replication $j$ and day $k(j=1-5, k=$ $1-2)$. This formula adjusts for inter-day variation in response and incorporates information from the solvent control as well as the positive control.

A BDI value of 0 indicates an effect similar to ethanol, while any value greater than 0 indicates biting deterrent effect relative to ethanol. BDI values not significantly different from 1, are statistically similar to DEET. BDI values were analyzed using SAS Proc ANOVA [31]. To determine whether confidence intervals include the values of 0 or 1 for treatments, Scheffe's multiple comparison procedure with the option of CLM was used in SAS [31]. LC 50 values for larvicidal data were calculated by using SAS, Proc Probit [31].

\section{Conclusions}

The essential oil of $M$. grandiflora seeds exhibited biting deterrent activity activity similar to DEET. All the major compounds (concentration $>1 \%$ ) except 1-decanol that were present only in seed essential oil were not active biting deterrents which indicated that the major activity of this essential oil might be due to 1-decanol. 1-Decanol also showed promising larvicidal activity. This high activity of 1-decanol indicated the potential of this compound to be developed as an effective mosquito population management tool. Further studies will be continued to evaluate these natural products in different formulations in large scale laboratory bioassays and field trials.

Supplementary Materials: The following are available online at http://www.mdpi.com/1420-3049/25/6/1359/s1. The total ion current (TIC) chromatogram of essential oils of the leaves, flowers, immature fruits, mature fruits and seeds of Magnolia grandiflora are available as supporting information (Figure S1).

Author Contributions: Conceptualization, A.A. and I.A.K.; sample collection and identification, V.R.; methodology, A.A., N.T., B.D., J.M.B., K.H.C.B.; formal analysis, N.T. and A.A.; resources, J.M.B. and V.R.; writing-original draft preparation, A.A. and N.T.; writing-review and editing, A.A., N.T., and V.R.; funding acquisition, I.A.K. All authors have read and agreed to the published version of the manuscript.

Funding: This study was supported in part by USDA/ARS grant No. 58-6066-6-043.

Acknowledgments: This study was supported in part by USDA/ARS grant No. 58-6066-6-043. We thank Dan Kline, Mosquito and Fly Research Unit, Center for Medical, Agricultural and Veterinary Entomology, USDA-ARS, Gainesville, for supplying mosquito eggs.

Conflicts of Interest: The authors declare no conflict of interest. Mention of trade names or commercial products in this publication is solely for the purpose of providing specific information and does not imply recommendation or endorsement by the U.S. Department of Agriculture. USDA is an equal opportunity provider and employer.

\section{References}

1. Ali, A.; Abbas, A.; Debboun, M. Zika virus: Epidemiology, vector and sexual transmission neurological disorders and vector management-A review. Int. J. Curr. Res. 2017, 10, 58721-58737.

2. $\quad$ Bhatt, S.; Weiss, D.J.; Cameron, E.; Bisanzio, D.; Mappin, B.; Dalrymple, U.; Battle, K.E.; Moyes, C.L.; Henry, A.; Eckhoff, P.A.; et al. The effect of malaria control on Plasmodium falciparum in Africa between 2000 and 2015. Nature 2015, 526, 207-211. [CrossRef]

3. Leal, W.S. The enigmatic reception of DEET-The gold standard of insect repellents. Currt. Opin. Insect Sci. 2006, 6, 93-98. [CrossRef]

4. Frances, S.P. Efficacy and safety of repellents containing DEET. In Insect Repellents: Principles, Methods and Uses; Debboun, M., Frances, S.P., Stickman, D., Eds.; CRC Press: New York, NY, USA, 2007; pp. 311-325.

5. Wedge, D.E.; Klun, J.A.; Tabanca, N.; Demirci, B.; Ozek, T.; Baser, K.H.C.; Liu, Z.; Zhang, S.; Cantrell, C.L.; Zhan, J. Bioactivity-guided fractionation and GC/MS fingerprinting of Angelica sinensis and Angelica archangelica root components for antifungal and mosquito deterrent activity. J. Agric. Food Chem. 2006, 57, 464-470. [CrossRef] [PubMed]

6. Tabanca, N.; Avonto, C.; Wang, M.; Parcher, J.F.; Ali, A.; Demirci, B.; Raman, V.; Khan, I.A. Comparative investigation of Umbellularia californica and Laurus nobilis leaf essential oils and identification of constituents active against Aedes aegypti. J. Agric Food Chem. 2013, 61, 12283-12291. [CrossRef] [PubMed] 
7. Ali, A.; Tabanca, N.; Demirci, B.; Blythe, E.K.; Baser, K.H.C.; Khan, I.A. Chemical composition and biological activity of essential oils from four Nepeta species and hybrids against Aedes aegypti (L.) (Diptera: Culicidae). Rec. Nat. Prod. 2016, 10,137-147.

8. Cantrell, C.L.; Maxwell, A.P.; Ali, A. Isolation and identification of mosquito (Aedes aegypti) biting-deterrent compounds from the native American ethnobotanical remedy plant Hierochloe odorata (Sweetgrass). J. Agric. Food Chem. 2016, 63, 447-456. [CrossRef]

9. Wang, Y.; Mu, R.; Wang, X.; Liu, S.; Fan, Z. Chemical composition of volatile constituents of Magnolia grandiflora. Chem. Nat. Compounds 2009, 45, 257-258. [CrossRef]

10. Rao, K.V.; Wu, W.N. Glycosides of Magnolia grandiflora. III: Structural elucidation of magnolenin C. J. Nat. Prod. 1978, 41, 56-62.

11. El-Feraly, F.S. Melampolides from Magnolia grandiflora. Phytochemistry 1984, 23, 2372-2374. [CrossRef]

12. Rao, K.V.; Davis, T.L. Constituents of Magnolia grandiflora. III. Toxic principle of the wood. J. Nat. Prod. 1982, 45, 283-287. [CrossRef] [PubMed]

13. Schuhly, W.; Ross, S.A.; Mehmedic, Z.; Fischer, N.H. Essential oils of the follicles of four North American Magnolia Species. Nat. Prod. Commun. 2008, 3, 1117-1119. [CrossRef]

14. Guerra-Boone, L.; Alvarez-Román, R.; Salazar-Aranda, R.; Torres-Cirio, A.; Rivas-Galindo, V.M.; Waksman de Torres, N.; González González, G.M.; Pérez-López, L.A. Chemical compositions and antimicrobial and antioxidant activities of the essential oils from Magnolia grandiflora, Chrysactinia mexicana, and Schinus molle found in northeast Mexico. Nat. Prod. Commun. 2013, 8, 135-138. [CrossRef]

15. Garg, S.N.; Kumar, S. Volatile constituents from the flowers of Magnolia grandiflora L. From Lucknow, India. J. Essent. Oils Res. 1999, 11, 633-634. [CrossRef]

16. Farag, M.A.; Al-Mahdy, D.A. Comparative study of the chemical composition and biological activities of Magnolia grandiflora and Magnolia virginiana flower essential oils. Nat. Prod. Res. 2013, 27, 1091-1097. [CrossRef] [PubMed]

17. Rao, B.R.R.; Sastry, K.P.; Saleem, S.M.; Rao, E.V.S.P.; Syamasundar, K.V.; Ramesh, S. Volatile flower oils of three genotypes of rose-scented geranium (Pelargonium sp.). Flavour Fragr. J. 2000, 15, 105-107.

18. Ali, A.; Tabanca, N.; Demirci, B.; Baser, K.H.C.; Ellis, J.; Gray, S.; Lackey, B.R.; Murphy, C.; Khan, I.A.; Wedge, D.E. Composition, mosquito larvicidal, biting deterrent and antifungal activity of essential oils of different plant parts of Cupressus arizonica var. glabra (Sudw.) Little ('Carolina Sapphire'). Nat. Prod. Commun. 2013, 8, 257-260. [CrossRef]

19. Ali, A.; Tabanca, N.; Kurkcuoglu, M.; Duran, A.; Blyhthe, E.K.; Khan, I.A.; Baser, K.H.C. Chemical composition, larvicidal and biting deterrent activity of essential oils of two subspecies of Tanacetum argenteum (Lam.) Willd. and individual constituents against Aedes aegypti (L.) (Diptera: Culicidae). J. Med. Entomol. 2014, 51, 824-830. [CrossRef]

20. Tabanca, N.; Gao, Z.; Demirci, B.; Techen, N.; Wedge, D.E.; Ali, A.; Sampson, B.J.; Werle, C.; Bernier, U.R.; Khan, I.A.; et al. Molecular and phytochemical investigation of Angelica dahurica and A. pubescens essential oils and their biological activity against Aedes aegypti, Stephanitis pyrioides and Colletotrichum Species. J. Agric. Food Chem. 2014, 62, 8848-8857. [CrossRef]

21. Ali, A.; Tabanca, N.; Ozek, G.; Ozek, T.; Aytac, Z.; Bernier, U.R.; Agramonte, N.M.; Baser, K.H.C.; Khan, I.A. Essential oils of Echinophora lamondiana (Apiales: Umbelliferae): A relationship between chemical profile and biting deterrence and larvicidal activity against mosquitoes (Diptera: Culicidae). J. Med. Entomol. 2015, 52, 93-100. [CrossRef]

22. Ali, A.; Cantrell, C.L.; Bernier, U.R.; Duke, S.O.; Schneider, J.C.; Khan, I. Aedes aegypti (Diptera: Culicidae) Biting deterrence: Structure-activity relationship of saturated and unsaturated fatty acids. J. Med. Entomol. 2012, 49, 1370-1378. [CrossRef] [PubMed]

23. Tabanca, N.; Bernier, U.R.; Ali, A.; Wang, M.; Demirci, B.; Blythe, E.K.; Khan, S.I.; Baser, K.H.C.; Khan, I.A. Bioassay-guided investigation of two Monarda essential oils for repellent activity against yellow fever mosquito Aedes aegypti. J. Agric. Food Chem. 2013, 61, 8573-8580. [CrossRef] [PubMed]

24. Flores-Estevez, N.; Vasquez-Morales, S.G.; Cano-Medina, T.; Sanchez-Velasquez, L.R.; Noa-Carrazana, J.C.; Diaz-Fleischer, F. Insecticidal activity of raw ethanolic extracts from Magnolia dealbata Zucc. on a tephritid pest. J. Environ. Sci. Health B 2013, 48, 582-586. [CrossRef] [PubMed]

25. McLafferty, F.W.; Stauffer, D.B. The Wiley/NBS Registry of Mass Spectral Data; J. Wiley and Sons: New York, NY, USA, 1989. 
26. Hochmuth, D.H. MassFinder 4.0, Hochmuth Scientific Consulting, Hamburg, Germany, 2008.

27. Klun, J.A.; Kramer, M.; Debboun, M. A new in vitro bioassay system for discovery of novel human-use mosquito repellents. J. Am. Mosq. Cont. Assoc. 2005, 21, 64-70. [CrossRef]

28. Ali, A.; Cantrell, C.L.; Khan, I.A. A new in vitro bioassay system for the discovery and quantitative evaluation of mosquito repellents. J. Med. Entomol. 2017, 54, 1328-1336. [CrossRef]

29. Katritzky, A.R.; Wang, W.; Slavov, S.; Dobchev, D.A.; Hall, C.D.; Tsikolia, M.; Bernier, U.R.; Elejalde, N.M.; Clark, G.G.; Linthicum, K.J. Novel carboxamides as potential mosquito repellents. J. Med. Entomol. 2010, 47, 924-938. [CrossRef]

30. Pridgeon, J.W.; Becnel, J.J.; Clark, G.G.; Linthicum, K.J. A high-throughput screening method to identify potential pesticides for mosquito control. J. Med. Entomol. 2009, 46, 335-341. [CrossRef]

31. SAS Institute. SAS Online Doc., version 9.2; SAS Institute: Cary, NC, USA, 2007.

Sample Availability: Samples of the compounds 1-decanol, 1-octanol, and 1-heptanol. are available from A.A..

(C) 2020 by the authors. Licensee MDPI, Basel, Switzerland. This article is an open access article distributed under the terms and conditions of the Creative Commons Attribution (CC BY) license (http://creativecommons.org/licenses/by/4.0/). 